\section{Patents, Designs and Trade Marks}

THE fifty-fifth report of the Comptroller-General of Patents, Designs and Trade Marks presents, as usual, a solid mass of information about the volume of business handled during 1937 in the Patent Office (Patents, Designs, and Trade Marks. Fifty-fifth Report of the Comptroller-General of Patents, Designs, and Trade Marks, with Appendices, for the Year 1937. Pp. 25. London: H.M. Stationery Office. 6d. net). Applications for patents, which should reflect the inventive activity of the country, went over the 35,000 mark during the year, and the work of the 821 members of the staff resulted in a surplus of close on $£ 300,000$. Two pages of the report are devoted to an account of the trend of invention to-day. Synthetic drugs, for example, sulphonamides, have had much attention, and hormones-to borrow a Stock Exchange phrase-are a strong feature. The special needs of bombers and bombs and the general demands of industry have caused the problems of getting and successfully using the extra-light metals magnesium and aluminium to be continuously tackled.

IN the patent field, application activity often diminishes in quarters where the main problems have been solved and the stage of bulk production has been reached. For this reason, applications for patent protection for mercury arc rectifiers have fallen off, but television applications are more than maintained. The report itself should be read to get a comprehensive survey, but one of the most curious instances of the application of science to the peculiar needs of modern life should be noted; inventors have been busy with various forms of chance-apparatus for use by those who fill up football-pool coupons. Patents make strange bed fellows and air raids precautions succeed pool coupons in the report. The Comptroller has clearly had a busy time with legislation, as 1937 saw both a Patents and a Trade Marks Bill introduced into Parliament. Of these, the Trade Marks Bill has now gone through all its stages and received Royal assent.

\section{Expenditure on Public Social Services}

A RETURn showing the total expenditure under certain Acts of Parliament in the financial years 1900, 1910 , $1920,1930,1935$ and 1936 on public social services has recently been issued, covering expenditure from local rates, Parliamentary votes and other receipts, not being loans or receipts for capital purposes. The first part of the return shows that the total expenditure on these services in England and Wales has increased from $£ 31.7$ millions in 1900 and $£ 54.95$ millions in 1910 to $£ 412 \cdot 8$ millions in 1930 and $£ 440.5$ millions in 1935. For 1936, the expenditure is estimated at 326 millions. The largest single item of expenditure is that under the Education Acts, which has increased from $16 \cdot 9$ millions in 1910 to 97 millions in 1935 . Expenditure under the General Scheme of Unemployment Benefit in 1935 was $45 \cdot 7$ millions and Unemployment Allowances and Benefits $38 \cdot 9$ millions. Expenditure under the Old Age Pensions Acts has risen from $6 \cdot 3$ millions in 1910 to 39 millions in 1935 , under the National Health Insurance Acts from 26 millions in 1920 to 34 millions in 1935. Under the Housing Acts expenditure has risen from 0.4 millions in 1900 to 42 millions in 1935, while under the Acts relating to the relief of the poor, expenditure has risen from 11.5 millions in 1900 to 44 millions in 1935. Public Health Acts now account for an expenditure of 16 millions as against a little over a million in 1900. Expenditure under the War Pensions Acts and Ministry of Pensions Act has decreased from 90.9 millions in 1920 to 36 millions in 1935 . Expenditure in Scotland on the same services shows similar trends, the total having risen from $\mathbf{1 4 . 3}$ millions in 1900 to $£ 50.3$ millions in 1935. Particulars of the number of persons benefiting from this expenditure are included.

\section{Training for Responsibility and Control}

A REPoRT on education, selection and training for positions of responsibility and control, by W. R. Dunlop, 57 Gordon Square, London, W.C.1, gives a summary of published views and methods in Great Britain with reference to executive and administrative positions in industry, commerce, agriculture, the civil services, the army, etc. Attention is directed to the confusion or disagreement as to management terminology in general, as to the main function of the educational system, the value of public school education and of social qualifications for positions of responsibility or control. On the other hand, the general agreement that, so far as management is concerned, the subject of a university degree does not greatly matter, which is emphasized by Mr. Dunlop, should be noted by scientific workers in supporting their claims for equal consideration for admission to administrative posts. Other matters on which there is general agreement are the necessity for avoiding excessive specialization in training; the importance of linking training for management with employment; the value of the "Case" method in specialized training; the un. reliability of selection by interview or examination and especially the unsatisfactoriness of committee interviewing.

Among many specific recommendations of the report are the recognition of the value of the psychological view in education, selection and training and of the importance of moral principles in management. An adequate article in the "Encyclopædia Britannica" is advocated, and in regard to general education the significance of history and geography is stressed. Views on the transfer of subjects problem require further investigation, and more attention should be paid to the wider aspects of selection, such as systems or policies, as well as to the forecasting of vacancies. Managerial job analysis, attention to the claims of older and not exclusively the younger men, probationary periods, to the theoretical side of training schemes in industry and the development of an administrative section in the libraries of Government departments and business firms are also recommended. In addition to the list of findings and recommendations, the report includes a fairly 